\title{
Reaction of street trees to adverse environmental conditions in the centre of Warsaw
}

\author{
*/**Wojciech Dmuchowski, *Aneta Baczewska, *Paulina Brągoszewska \\ *Botanical Garden-Center for Conservation of Biological Diversity, \\ Polish Academy of Science, Prawdziwka St. 2, 02-973 Warsaw, Poland \\ e-mail: dmuchowski@ob.neostrada.pl \\ ${ }^{* *}$ Warsaw University of Life Sciences-SGGW, Faculty of Agriculture and Biology, \\ 159 Nowoursynowska, 02-776 Warsaw, Poland
}

\begin{abstract}
The present study aimed atanalysing the trees growing along the four main streets of Warsaw - Marszałkowska, Świętokrzyska, Jana Pawła II and Solidarności Avenues - in order to evaluate the condition of each of them. The observations made in 1973 and in 2007 revealed that in this time the trees passed from 1631 to 1014, which stands for 40.3\% of the original number. The biggest loss was noted for species: Sorbus aucuparia L. (94\%), Acer pseudoplatanus L. (83\%), Tilia cordata Mill. (65\%) and Tilia 'Euchlora' (62\%). None of the species, that were growing in 1973, could have been more tolerant to the specific environmental conditions in the vicinity of the road. The observations made in September had shown that the most frequent average value of the leaf damage index was above 3. The growing of this index showed that as vegetation period was passing by the condition of the trees was getting worse.The comparison of the leaf damage index carried out in September showed that in 2007 the health condition in 2007 was slightly better than in 1973 .
\end{abstract}

Key words: city environment, trees declining, de-icing.

\section{Introduction}

The greenery is one of the essential components of urban landscape in which trees play an important role in levelling ecological, scenic and health values of the city. Trees shape the local climate by influencing sunlight exposure, temperature, humidity, pollution levels as well as air exchange rates (Szczepanowska 2001; Kubiak \& Księżniak 2005).

Trees complex reactions to natural and anthropogenic stressors often result in their exclusion from many regions of urban agglomerations (Bach et al. 2007). For the decades we have been observing the trees the declining was caused by gradual weakening of their vitality. This process usually affects mainly trees growing in the vicinity of the roads. The drawbacks of the city environment, such as soil salinity (caused by de-icing of the roads), constant changes of city climate (elevated temperature, reduced air humidity), traffic (high levels of fumes and dust), limit the choice of the species and varieties of trees and shrubs that can be planted within the city (Szyprowski 2000).

Observing the existing trees, learning their history and assessing their adaptiveness should always precede the choose of the species of trees to plant in a city (Richards 1993).

The aim of this research was to value the sensitivity (vulnerability) of particular species of trees to the unfavourable conditions of growth and development in Warsaw's street plantings. 


\section{Methodology}

The research have been carried out along four main streets of Warsaw's centre: Marszałkowska and Świętokrzyska Streets and Jana Pawła II and Solidarności Avenues. The inventory of all the trees planted along those streets have been made. The trees were observed in 1973 and in 2007. The evaluation of the trees condition was made separately for each tree, in accordance with the trees condition table prepared by Duda et al. (1994). The leaf damage index was evaluated with a use of six-grade scale; where 0 - stands for leaves without a damage, while 5 stands for leaves with a significant damage (over $75 \%$ of the leaf's surface). The observations were made twice a year - in mid-July and in mid-September.

\section{Results}

The results of trees inventory are depicted in Figures 1 and 2 and presented in Table 1. In 1973, along the four streets indicated 1631 trees were growing, whilst in 2007 - only 1014. It means that the number of the trees decreased by 617, which stands for $38 \%$. From 1973 to 2007 only 658 trees that were growing along those streets had survived, which stands for $41 \%$. In this period 357 trees had been planted.

In Oakland from 1978 to 1984 about $60-70 \%$ of street trees withered away (Skalar \& Ames 1985). According to Gilbertson and Brandshaw (1985) water stress (56\%), acts of vandalism (18\%), condensation of soil solution (9\%) are the most common reasons of trees declining, while according to Patterson et al. (1980) the unfavourable soil conditions result in worsening trees condition. In Poland the main reason of street trees declining is, probably, the saline stress due to the de-icing streets and pathways by the use of salt ( $\mathrm{NaCl})$ (Czerwiński 1978; Chmielewski et al., 1999; Brogowski et al. 2000; Dmuchowski et al. 2001, 2005; Dmuchowski \& Badurek 2001, 2003, 2004; CzerniawskaKusza et al. 2004).

In Marszałkowska Street in 1973766 trees had been growing whilst in 2007 only 476: the number of trees declined by 270 , which stands $38 \%$. In last 34 years 486 trees have withered away (70\%). In that period 200 trees had been planted. In 1973 the dominating species was Tilia 'Euchlora' (66\% of the trees) but during last 34 years $64 \%$ of these trees declined. The loss of other species trees was high too: Tilia cordata (65\%), Tilia x floribunda A. Braun (60\%), Tilia platyphyllos Scop. (58\%), Acer saccharinum L. (90\%). All Horse-chestnut trees survived (Aesculus hippocastanum L.) while all Norway Maples (Acer platanoides L.) withered away. After street modernisation in 200339 Tilia tomentosa 'Brabant' trees and 28 Tilia platyphyllos trees were planted. During the extremely cold winter of 2003/2004 Tilia tomentosa 'Brabant' trees were severely damaged by frost (Dmuchowski 2004).

From among 366 trees growing in Jana Pawła II Avenue in 1973 only 162 had survived till 2007, which stands for 44\%. During that period 35 trees had been planted, which resulted in a decrease of $169(46 \%)$ in total number of trees. In 1973 the dominating species was Acer saccharinum $(67 \%)$. About $49 \%$ of this species trees declined. The biggest loss was noted for Sorbus aucuparia (94\%). The trees considered as less sensitive to the urban environment were planted, Platanus x hispanica Mill., oaks: Quercus rubra L. and Quercus robur L. (Lukaszewicz 1982; Bugała 1991; Marczewski 1996; Siewniak \& Siewniak 2001; Appleton et al. 2002; Borowski \& Latocha, 2006) and Acer saccharinum highly sensitive to the unfavourable growth condition, are not mentioned in the indices of trees recommended for urban greenery.

In Świętokrzyska Street 274 trees had been growing in 1973, whilst in 2007 only 181. The number of trees declined by 93 specimen (34\%). In the last 34 years 486 trees have withered away (70\%). Fromtrees growing there in 1973 only 100 trees had survived till 2007, which stands for $37 \%$. The dominating species was Acer platanoides $(87 \%)$ and the loss for this species was noted as $61 \%$. Trees of Platanus x hispanica, known as less sensitive to the conditions of urban environment, have been planted.

In Solidarności Avenue the smallest loss was noted. From 225 trees growing there in 1973120 had survived till 2007, which stands for 53\%. During that period 40 trees had been planted, which resulted in a decrease of $30 \%$ in total number of the trees within a period of 34 years. The dominating species was Acer platanoides (83\%) and the loss for this species was noted as $52 \%$.

The health condition of the trees growing along the four main streets of Warsaw is depicted in the charts (Fig. 3 and 4). This settlement includes only the trees that survived from 1973 to 2007 . The first symptoms of the trees reaction to soil salinity are discolouration and necrosis of the leaves (Strogonov 1970). At the beginning of the vegetation period, in early spring, the changes appear on the top part of the edges of the leaf lamina. However, as a result of the increase in the chlorine and sodium concentrations in the leaves, the degree of leaf-damage also increases (Makdashi et al. 1988).

The health condition of the examined trees was exceptionally poor. The average value of the leaf damage index in the research carried out in September 1973 fluctuated from 1.7 (for Tilia x floribunda) to 4.6 (for Tilia 'Euchlora'). In 2007 the value of this index for Tilia x floribunda increased to 3.1. In 2007 the index in the research carried out in an analogous period of observation fluctuated from 2.5 (for Acer pseudoplatanus) to 4.0 (for Sorbus aucuparia and Tilia 'Euchlora'). The best health condition 


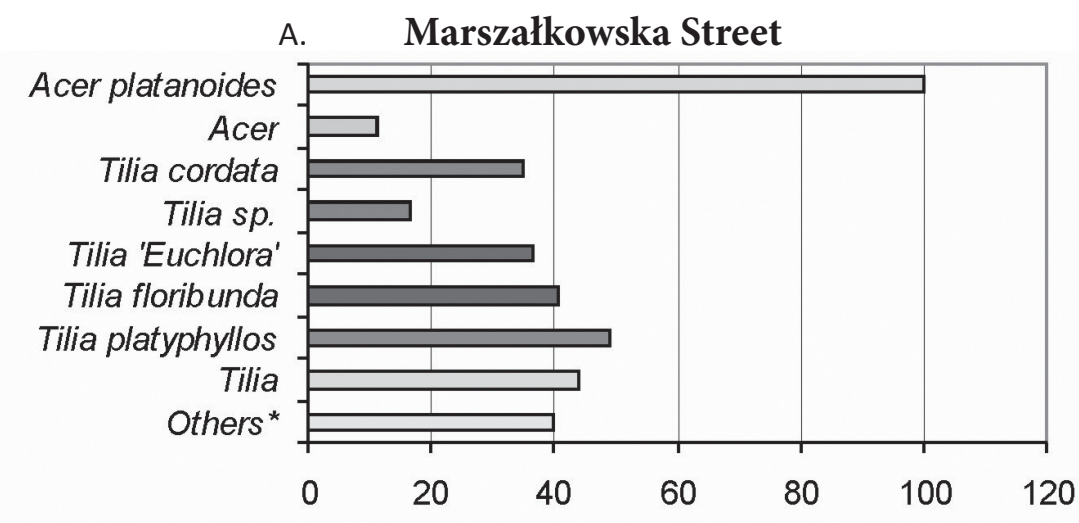

\section{B. Jana Pawła II Avenue}

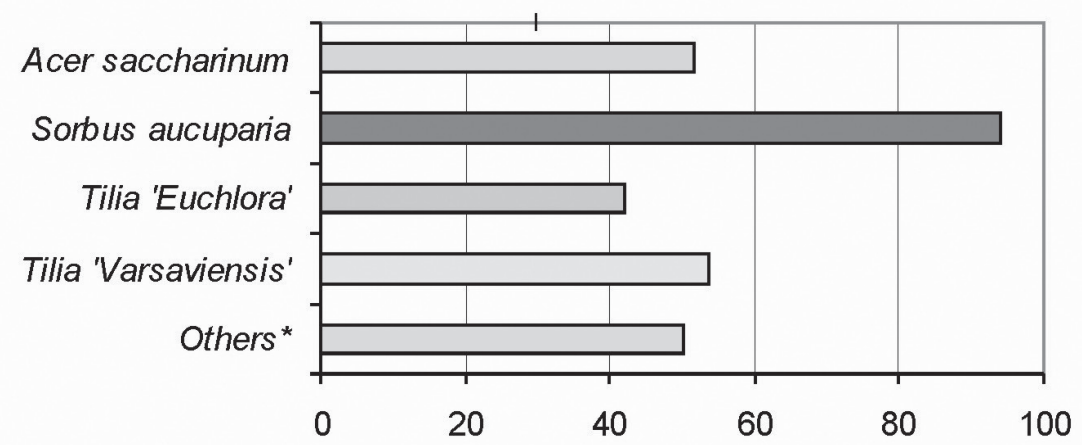

C. Świętokrzyska Street

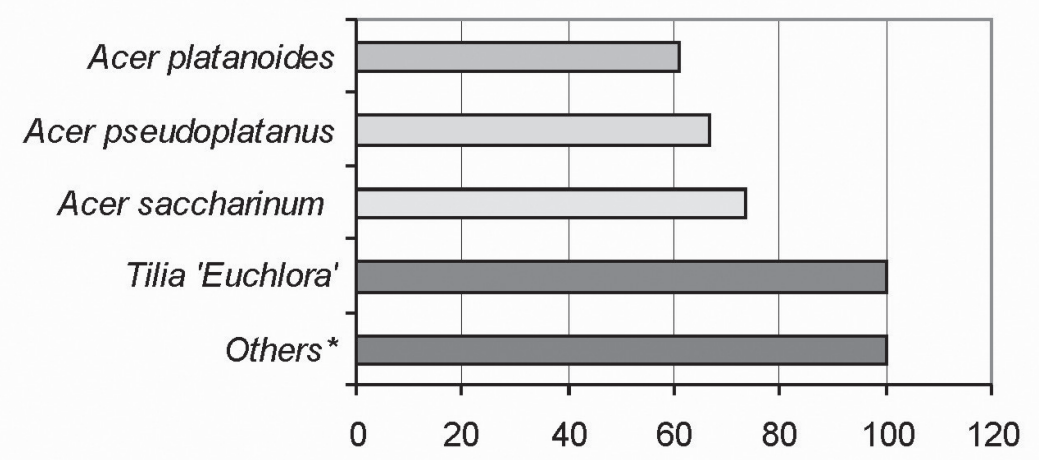

\section{Solidarności Avenue}

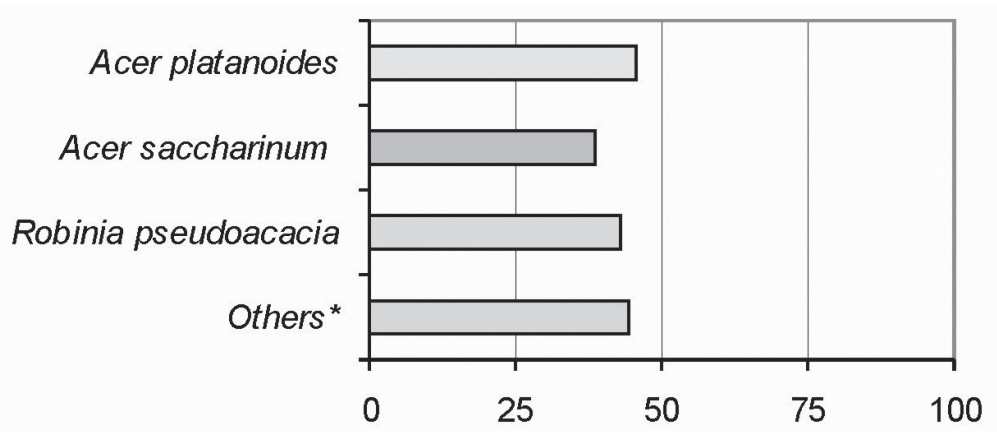

Figure 1. Percentages of each species of dead trees at the four major streets of Warsaw in the years 1973-2007 


\section{A. Marszałkowska Street}

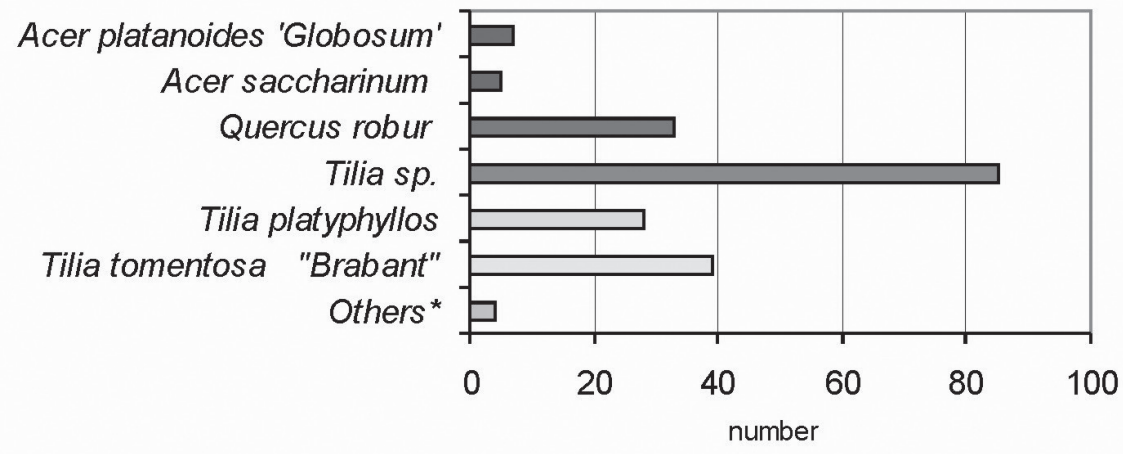

B. Jana Pawła II Avenue

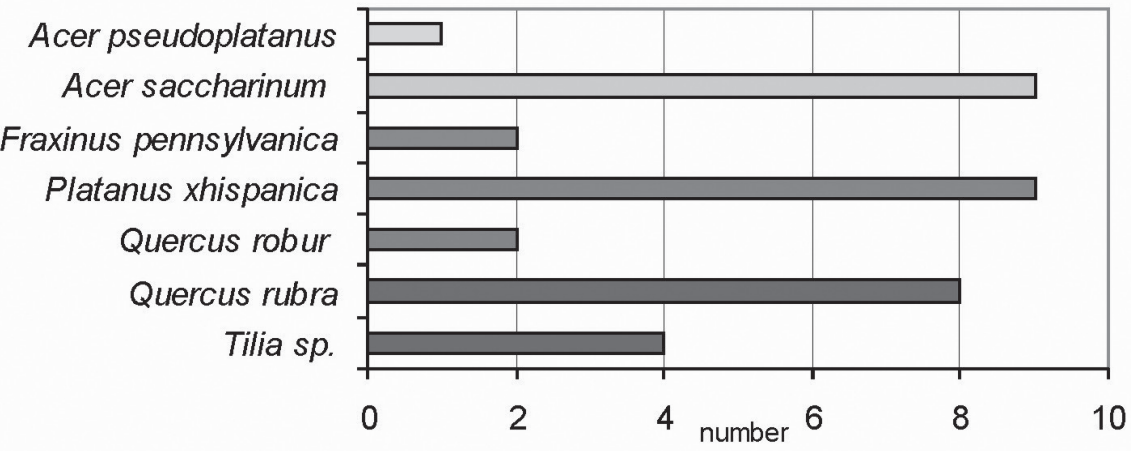

C. Świętokrzyska Street

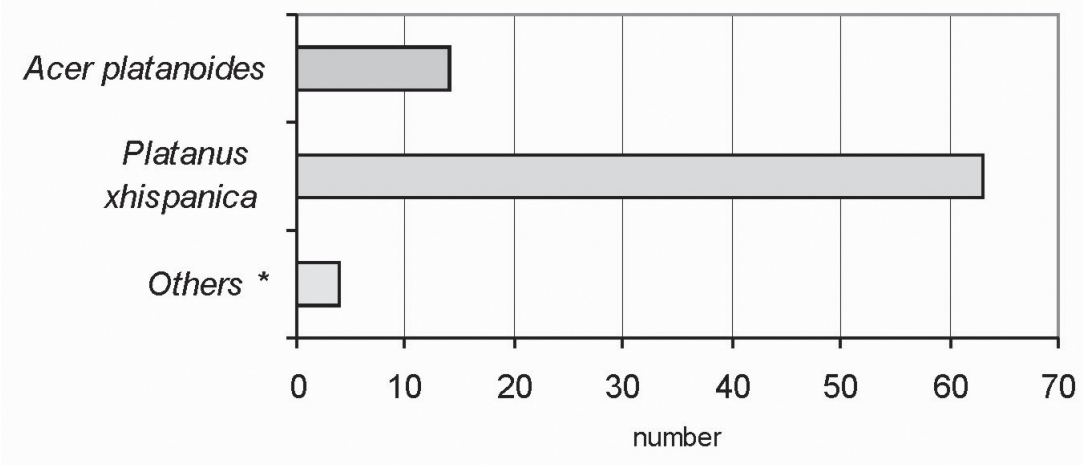

D. Solidarności Avenue

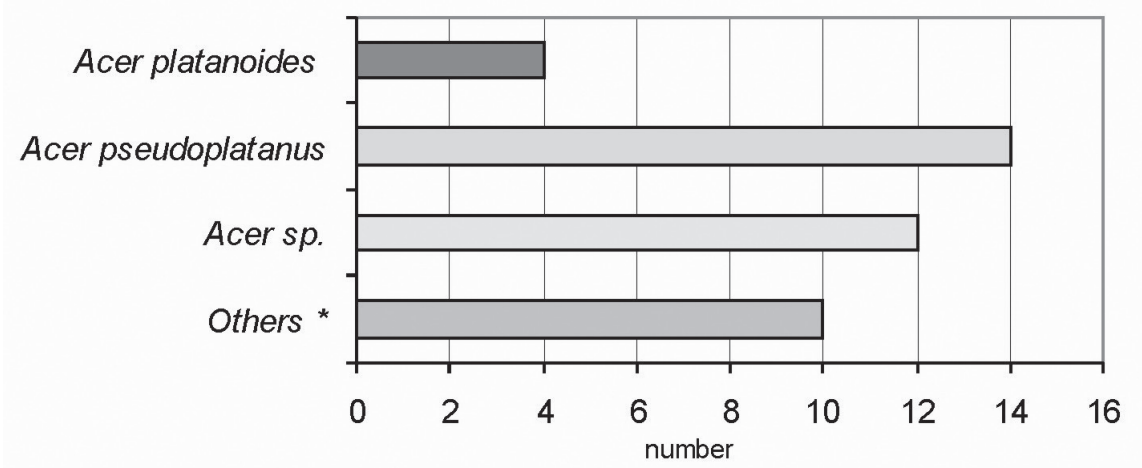

Figure 2. Number of trees in different taxons planted at the four main streets of Warsaw in the years 1973-2007 
A. Marszałkowska Street

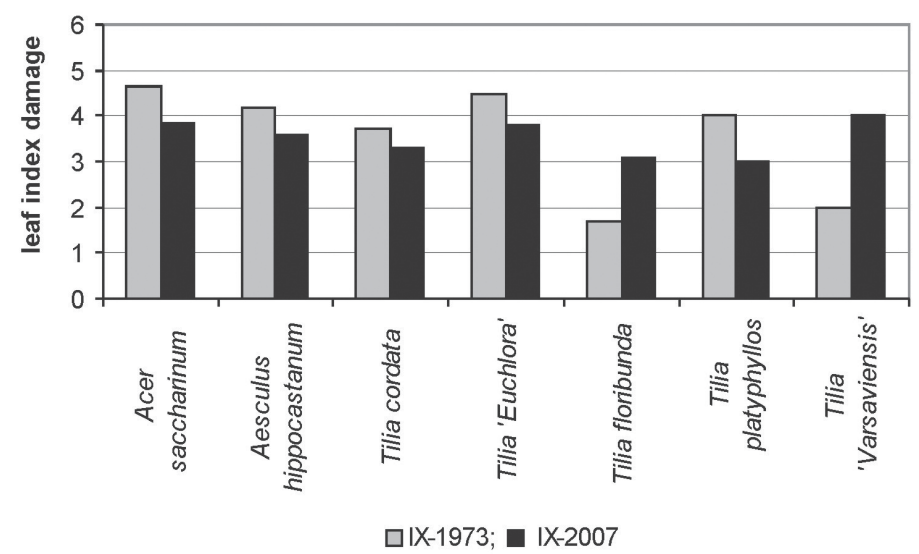

B. Jana Pawła II Avenue

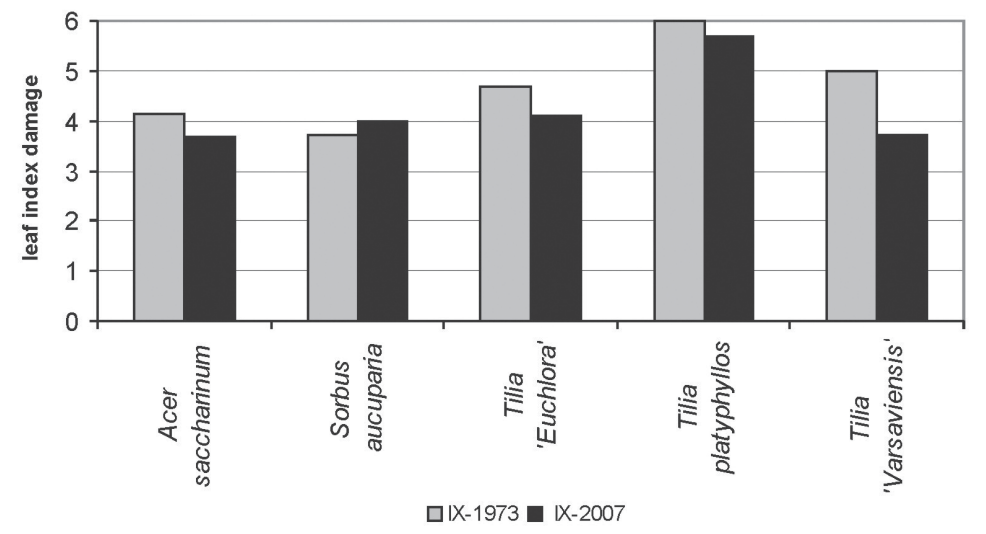

C. Świętokrzyska Street

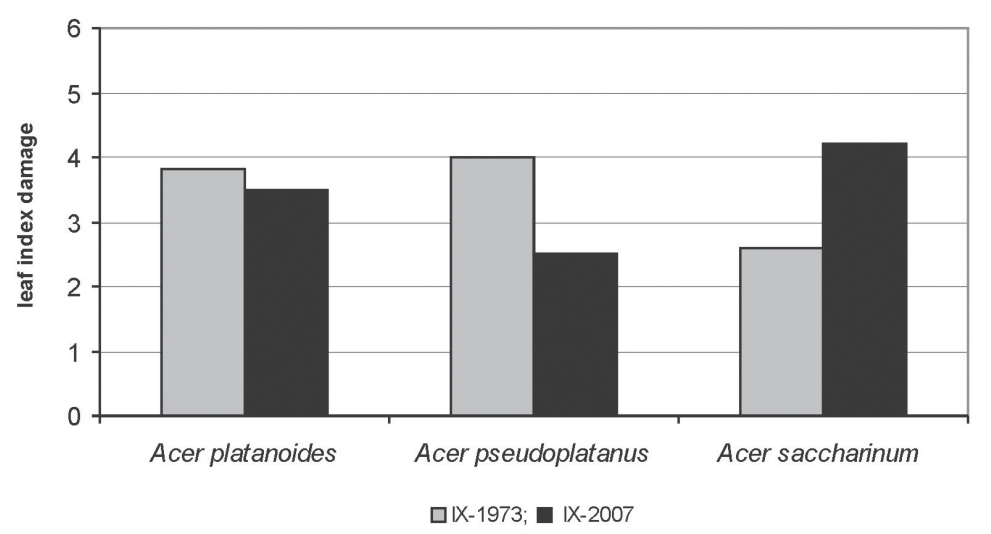

D. Solidarności Avenue

Figure 3. Comparison of health status of leaves (damage index) of trees from the main streets of Warsaw (the average for the species), the September 1973-2007 period of observation

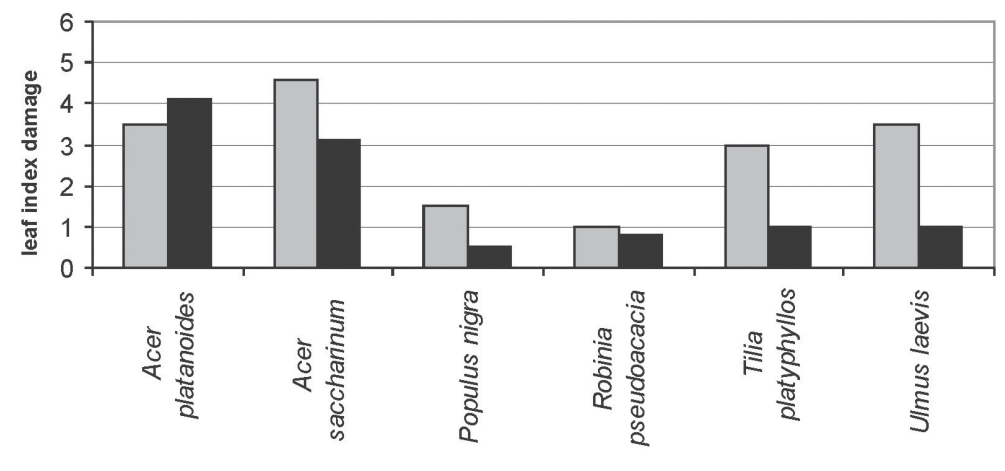

口IX-1973; - XX-2007 
Table 1. Summary results of the inventory of trees growing along the main streets of downtown of Warsaw in the years 1973 and 2007

\begin{tabular}{|c|c|c|c|c|c|c|c|}
\hline \multirow{2}{*}{ 1.p. } & \multirow{2}{*}{ Taxon } & \multicolumn{2}{|c|}{ Year } & \multicolumn{2}{|c|}{ Growing from 1973} & \multirow{2}{*}{$\begin{array}{c}\text { Cut off } \\
(\%)\end{array}$} & \multirow{2}{*}{$\begin{array}{l}\text { Planted } \\
\text { number }\end{array}$} \\
\hline & & 1973 & 2007 & number & $(\%)$ & & \\
\hline 1 & Acer negundo & 4 & 1 & 1 & & & \\
\hline 2 & Acer platanoides & 431 & 205 & 191 & 44.3 & 55.7 & 14 \\
\hline 3 & Acer platanoides (red variety) & 0 & 4 & & & & 4 \\
\hline 4 & Acer platanoides 'Globosum' & 0 & 7 & & & & 7 \\
\hline 5 & Acer pseudoplatanus & 12 & 17 & 2 & 16.6 & 83.4 & 15 \\
\hline 6 & Acer saccharinum & 341 & 151 & 137 & 42.0 & 58.0 & 14 \\
\hline 7 & Acer sp. & 0 & 13 & & & & 13 \\
\hline 8 & Aesculus hippocastanum & 6 & 6 & 5 & 83.3 & 16.7 & 1 \\
\hline 9 & Catalpa speciosa & 0 & 1 & & & & 1 \\
\hline 10 & Crataegus sp. & 2 & 1 & & & & 1 \\
\hline 11 & Fraxinus americana & 1 & 1 & 1 & & & \\
\hline 12 & Fraxinus exelsior & 0 & 1 & & & & 1 \\
\hline 13 & Fraxinus pennsylvanica & 0 & 2 & & & & 2 \\
\hline 14 & Platanus x hispanica & 0 & 72 & & & & 72 \\
\hline 15 & Populus sp. & 5 & 4 & 3 & & & 1 \\
\hline 16 & Prunus avium & 1 & 0 & & & & \\
\hline 17 & Pyrus communis & 0 & 2 & & & & 2 \\
\hline 18 & Quercus robur & 0 & 35 & & & & 35 \\
\hline 19 & Quercus rubra & 0 & 8 & & & & 8 \\
\hline 19 & Quercus sp. & 5 & 1 & & & & 1 \\
\hline 20 & Robinia pseudoacacia & 7 & 4 & 4 & 57.1 & 45.9 & \\
\hline 21 & Sorbus aria & 0 & 1 & & & & 1 \\
\hline 22 & Sorbus aucuparia & 51 & 4 & 3 & 5.9 & 94.1 & 1 \\
\hline 23 & Sorbus sp. & 0 & 1 & & & & 1 \\
\hline 24 & Tilia cordata & 20 & 7 & 7 & 35.0 & 65.0 & \\
\hline 25 & Tilia 'Euchlora' & 565 & 215 & 215 & 38.0 & 62.0 & \\
\hline 26 & Tilia $\mathrm{x}$ floribunda & 91 & 37 & 37 & 40.7 & 59.4 & \\
\hline 27 & Tilia platyphyllos & 72 & 67 & 39 & 54.2 & 44.2 & 28 \\
\hline 28 & Tilia 'Stellata' & 2 & 0 & & & & \\
\hline 29 & Tilia sp. & 8 & 93 & 2 & 25.0 & 75.0 & 91 \\
\hline 30 & Tilia tomentosa 'Brabant' & 0 & 39 & & & & 39 \\
\hline 31 & Tilia 'Varsaviensis' & 20 & 9 & 9 & 45.0 & 55.0 & \\
\hline 32 & Tilia $\mathrm{x}$ europaea & 0 & 1 & & & & 1 \\
\hline 33 & Ulmus glabra & 0 & 1 & & & & 1 \\
\hline \multirow[t]{2}{*}{34} & Ulmus laevis & 2 & 2 & 2 & & & \\
\hline & Total & 1631 & 1013 & 658 & 40.6 & 59.6 & 357 \\
\hline
\end{tabular}




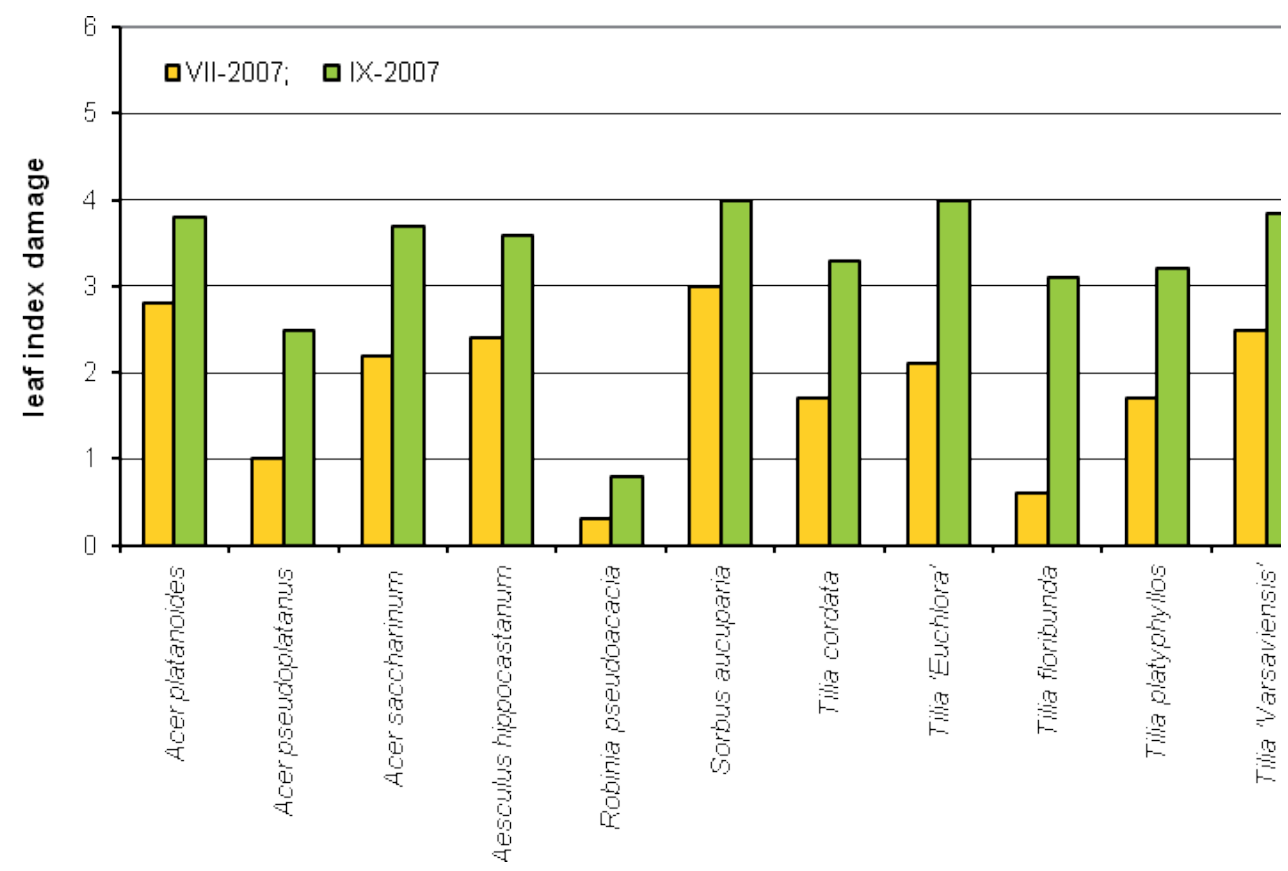

Figure 4. Comparison of health status of leaves (damage index) of trees from the main streets of Warsaw (average for the species) the July and September period of observation

of the leaves was noted for Robinia pseudoacacia L. The poorest health condition of the leaves was noted for Tilia 'Euchlora'. The leaf damage index value for both of them was 4.6 in 1973 and 4.0 in 2007 . For these species the biggest loss $(62 \%)$ was noted.

The comparison of the leaf-damage index measured in mid-September indicated that in 1973 the health condition of the observed trees was slightly worse than in 2007. This could be caused by the mild winters of those years. Sorbus aucuparia was the only species for which the leaf-damage index was higher in 2007. Also the biggest loss was noted for this particular species: $90 \%$ within 34 years reporting period.

The comparison of the leaf-damage index measured in mid-September and in mid-June shows significant worsening of the health condition of the trees as vegetation period is passing by. This phenomenon was noted for all of the observed species. Platanus $\mathrm{x}$ hispanica stood out from the new street plantings. Its health condition indicated that it is a species resistant to the specific climatic and soil conditions of the cities (Chmielewski \& Molski 1986; Siewniak \& Siewniak 2002; Borowski \& Latocha 2006).

The inventory carried out in Warsaw had shown that the main streets are planted with the trees of the species sensitive to the urban stresses (specially soil salinity), such as Maples and Lime Trees. Consequently within 34 years more than $60 \%$ of the street trees had declined. Hence it is necessary to carry out the research on the growth and development of trees in varied environmental conditions in order to adapt the composition of the species to the "difficult and demanding" city environment.

\section{Conclusions}

The following conclusions can be drawn based on the observations carried out within the framework of this study:

1. The number of the trees growing alonf the four main streets of Warsaw declined from 1631 trees in year 1973 to 1014 in 2007 . Hence, the number of trees declined by 617 , which stands for $38 \%$. In the reporting period 357 trees had been planted and survived till 2007.

2. The biggest loss was noted for Sorbus aucuparia 94\%, Acer pseudoplatanus 83\%, Tilia cordata 65\% and Tilia 'Euchlora' 62\%. The smallest loss was noted for Tilia platyphyllos, but still it was estimated as $44 \%$. None of the species, that were growing in 1973, stood out as more tolerant to the specific environmental conditions in the vicinity of the road in Warsaw.

3. The health condition of the leaves of the trees of most common species was poor. In mid-September observation the average value of the leaf-damage index exceeded 3. Trees of that health condition cannot perform none of their basic functions.

4. The comparison of the leaf-damage index measured in mid-September indicates that in 1973 the health condi- 
tion of the observed trees was slightly worse than in 2007. This can be caused by the mild winters of those years.

5. The comparison of the leaf-damage index measured in mid-September and in mid-June shows significant worsening of the health condition of the trees as vegetation period is passing by. This phenomenon was noted for all the observed species.

6. Platanus $\mathrm{x}$ hispanica stood out from the new street plantings.

7. The poorest health condition of the leaves was noted for Tilia 'Euchlora', both in 1973 and in 2007. For this species the biggest loss $(62 \%)$ was noted.

\section{References}

Appleton B., Horsley., Harris V., Eaton G., Fox L., Orband J. \& Hoysa C., 2002, Trees for parking lots and paved areas, Trees for Problem Landscape Sites, Virginia Cooperative Extension, Blackburg, VA.

Bach A., Frazik-Adamczyk M., Pawłowska B. \& Pniak M., 2007, Wpływ warunków miejskich na zdrowotność lip (Tilia x europea 'Pallida') w alei Najświętszej Marii Panny w Częstochowie [The effect of urban conditions on health status of Common Lime (Tilia $\mathrm{x} \mathrm{eu}$ ropea 'Pallida') at the Virgin Mary Avenue in Czestochowa], Roczniki Akademii Rolniczej w Poznaniu CCCLXXXIII, Ogrodnictwo 41: 11-16.

Borowski J. \& Latocha P., 2006, Dobór drzew i krzewów do warunków przyulicznych Warszawy i miast centralnej Polski [Trees and shrubs suitable for street conditions in Warsaw and other cities in central Poland], Rocznik Dendrologiczny 54: 93-93.

Brogowski Z., Czarnowska K., Chojnicki J., Pracz J.\& Zagórski Z., 2000, Wpływ stresu solnego na stan chemiczny liści drzew $\mathrm{z}$ terenu Łodzi [Effect of salinity stress on the chemical status of leaves of trees from the city of Łódź], Roczniki Gleboznawcze 1/2: 17-28.

Bugała W., 1991, Drzewa i krzewy [Trees and shrubs], Państwowe Wydawnictwo Rolnicze i Leśne, Warszawa: 594.

Chmielewski W., Dmuchowski W. \& Supłat S., 1999, Impact of urban environmental pollution on growth, leaf damage and chemical constituents of Warsaw Urban Trees, Proceedings of the International Symposium on Air Pollution and Climate Change Affects on Forest Ecosystems, Riverside, USA, February 5-9 1996, USDA Forest Service, General Technical Report, PSWGTR-166: 215-220.

Chmielewski W. \& Molski B., 1986, Badania nad przydatnością platana do zadrzewień przyulicznych [Studies on the usefulness of Platanus to the street planting], Ogrodnictwo 6: 18-21.
Czerniawska-Kusza I., Kusza G. \& Dużyński M., 2004, Effect of deicing salts on urban soils and health status of roadside trees in the Opole Region, Environmental Toxicology 19: 296 - 301.

Czerwiński Z., 1978, Wpływ chemicznej technologii odśnieżania ulic na gleby i roślinność drzewiastą aglomeracji miejskich [The effect of chemical technology of snow removal on the soil and vegetation of urban trees], Zeszyty Naukowe SGGW-AR, Rozprawy Naukowe 104: 42.

Dmuchowski W, Sołtykiewicz E. \& Gozdowski D., 2005, Reakcja Quercus rubra L. na zakłócenie równowagi jonowej spowodowanej różnym stopniem zasolenia gleby [The reaction of Quercus rubra L. in ionic imbalance caused by varying degrees of soil salinity], [in:] B. Gworek (ed.), Obieg Pierwiastków w Przyrodzie [Circulation of chemical elements in Nature], III: $506-510$.

Dmuchowski W. \& Badurek M., 2001, Zmiany składu chemicznego liści drzew pod wpływem środowiska miejskiego [Changes in chemical composition of leaves of trees under the influence of the urban environment], [in:] B. Gworek, A. Mocka (eds.), Obieg Pierwiastków w Przyrodzie [Circulation of chemical elements in $\mathrm{Na}$ ture], I: 218-224.

Dmuchowski W. \& Badurek M., 2003, Chlorine contents in the leaves of tree species characterized with relatively greater resistance to the adverse urban conditions, [in:] B. Gworek, J., Misiak (eds.), Obieg Pierwiastków w Przyrodzie [Circulation of chemical elements in $\mathrm{Na}-$ ture], II: 309-312.

Dmuchowski W., Badurek M., 2004, Chloride and sodium in the leaves of urban trees in Warsaw in connection to their health condition. Chemia i Inżynieria Ekologiczna, 11 (4-5): 297-303.

Dmuchowski W., Kurczyńska E., Chmielewski W. \& Badurek M., 2001, Growth and development of Crimean linden in street planting, [in:] R. Siwicki (ed.), Reakcje Biologiczne Drzew na Zanieczyszczenia Przemysłowe, [Biological response of trees to industrial contamination], Wydawnictwo Bogucki, Poznań: 629-635.

Dmuchowski W., Sołtykiewicz E. \& Woźniak J., 2007, The effect of urban environment on the phenological development of Tilia 'Euchlora' trees. Monographs of Botanic Garden 141-145.

Dmuchowski W., 2004, Stan zdrowotny oraz zalecenia pielęgnacyjne dla nowo posadzonych drzew Tilia tomentosa 'Brabant' rosnących przy ulicy Marszałkowskiej, na odcinku Rondo Dmowskiego - Plac Konstytucji [The state of health and care recommendations for newly planted trees, Tilia tomentosa 'Brabant' growing on Marszałkowska Street for a distance of Dmowski Rondo - Konstytucji Square], typescript. 
Duda J., W: Włoch W., Bełtowski M. \& Muszyńska J., 1994, Inwentaryzacja dendrologiczna zespołu alei, [in:] Aleja Husarii Polskiej z alejami bocznymi na tle rezerwatu Łężczak w Kotlinie Raciborskiej, Wika S., Włoch W. (eds.) [Dendrological inventory of team avenue], Scripta Rudensica 3: 37-55.

Gilbertson P. \& Bradshaw A.D., 1985, Tree survival in cities: the Entent and nature of the problem, Arboricultural Journal 9: 131-142.

Kubiak J., Księżniak A., 2005, Przyrodnicze uwarunkowania zadrzewień na obszarach zurbanizowanych [Natural conditioning of aforestation inurbanized areas], Teka Kom. Arch. Urb. Stud. Krajobr. - OL PAN, 2005: 168-176.

Łukasiewicz A., 1982, Kryteria prawidłowego rozwoju terenów zieleni w aglomeracjach miejskich na przykładzie miasta Poznania [Criteria for the proper development of green spaces in urban areas on the example of the city of Poznań], Seria Biologia, Wydawnictwo Nauk. Uniwersytetu im. Adama Mickiewicza, Poznań, 21: $1-62$.

Marczewski A., 1996, Czy drzewa mogą rosnąć w Warszawie? [Whether the trees can grow in Warsaw?], Zieleń Warszawy problemy i nadzieje [Greenery of Warsaw, Problems and hopes], Konferencja naukowo-techniczna, 6 września 1996 r., Warszawa-Powsin: 155-163.
Mekdaschi R., Horlacher D., Schulz R. \& Marschner H., 1988, Streusalzschäden und Sanierungsmassnahmen zur Verminderung der Streusalzbelastung von Strassenbäumrn in Stuttgart, Angew, Botanik 62: 355-371.

Patterson J. C., Murray J. J. \&. Short J. R, 1980, The Impact of Urban Soils on Vegetation, Proceedings of the third conference of the Metropolitan Tree Improvement Alliance (METRIA) 3: 33-56.

Richards N.A., 1983, Reasonable Guidelines for Street Tree Diversity, Journal of Arboriculture 19: 56-70.

Siewniak M. \& Siewniak M., 2001, Basic problems of growing trees in the streets. Zieleń Warszawy Problemy i Nadzieje, Konferencja Naukowo-Techniczna, Warszawa-Powsin, październik 2001: 33-55

Sklar F. \& Ames R. G., 1985, Staying alive: street tree survival in the inner-city, J. Urban Affairs 7 (1): 55-65.

Szczepanowska H., 2001, Drzewa w mieście [Trees in the city], Wydawnictwo Hortpress Sp. z.o.o, Warszawa.

Szypowski J., 2000, Próba doboru gatunków i odmian drzew do nasadzeń przyulicznych w Warszawie [Trying of selection for species and varietes of trees suitable for street conditions in Warsaw], Ogrodnictwo 3: 27-29. 